\title{
PENGARUH PENDIDIKAN KESEHATAN MELALUI MEDIA VIDEO TERHADAP KECEMASAN MENGHADAPI PERSALINAN PADA IBU PRIMIGRAVIDA TRIMESTER III DI WILAYAH KERJA PUSKESMAS BLABAK KEDIRI
}

\author{
Shinta Kristianti ${ }^{1}$, Suwoyo $^{2}$, Ika Yuni Pratiwi ${ }^{3}$ \\ 1,2,3 Jurusan Kebidanan, Poltekkes Kemenkes Malang
}

\begin{abstract}
Abstrak
Kehamilan pertama bagi seorang ibu (primigravida) merupakan salah satu periode krisis dalam kehidupannya. Pada trimester ketiga sering disebut sebagai periode penantian dengan penuh kewaspadaan. Rasa cemas dan takut terhadap proses persalinan akan dapat meningkat. Kecemasan mempunyai efek negatif bagi ibu hamil (khususnya hamil pertama), dengan adanya kecemasan akan meningkatkan kadar katekolamin sehingga dapat mengganggu kemajuan persalinan yang berakibat pada kejadian partus lama. Kecemasan terjadi pada ibu dengan pengetahuan yang rendah mengenai proses persalinan. Hal ini dikarenakan kurangnya informasi yang diperoleh, tidak adanya gambaran bagaimana persalinan yang akan dilaluinya. Penelitian ini bertujuan untuk mengetahui pengaruh pendidikan kesehatan yang diberikan melalui pemberian video tentang persalinan pada ibu primigravida trimester III terhadap kecemasan menghadapi persalinan. Desain penelitian ni merupakan adalah pra eksperimen dengan rancangan One Group Pretest Posttest. Populasi penelitian sejumlah 15 ibu hamil, dengan simple random sampling didapatkan sampel 14 responden. Instrumen penelitian yang digunakan adalah kuesioner DASS, dianalisis dengan Wilcoxon Match Pairs Test menggunakan taraf kesalahan 0.05 maka $Z_{\text {tabel }}(1.645)<Z_{\text {hitung }}$ (3.295). Hasil penelitian menunjukkan ada pengaruh pendidikan kesehatan pada ibu primigravida trimester III tentang persalinan dengan media video terhadap kecemasan menghadapi persalinan di wilayah kerja Puskesmas Blabak Kediri. Media edukasi tentang persalinan dapat divariasikan sehingga akan menambah tingkat pemahaman dan berpengaruh pada kecemasan ibu hamil treimester tiga yang akan melalui proses persalinan.
\end{abstract}

Kata Kunci : Kecemasan, Pendidikan Kesehatan, Video, Primigravida

\section{THE EFFECT OF HEALTH EDUCATION THROUGH VIDEO MEDIA ON ANXIETY WITH LABOR IN TRIMESTER III PRIMIGRAVIDA MOTHER IN PUSKESMAS BLABAK KEDIRI}

Abstract

The first pregnancy for a mother (primigravida) is one of the crisis periods in her life. The third trimester is often referred to as the period of vigilance. You can increase your anxiety and fear about labor. Anxiety has a negative effect on pregnant women (especially first pregnancies), with anxiety it will increase catecholamine levels so that it can interfere with the progress of labor which results in prolonged labor. Anxiety occurs in mothers with low knowledge of the birthing process. This is due to the lack of information obtained, no description of how the delivery will go. This study aims to determine the effect of health education provided through video delivery of third trimester primigravida mothers on anxiety facing childbirth. This 
research design is a pre-experiment with the One Group Pretest Posttest design. The study population was 15 pregnant women, with simple random sampling obtained a sample of 14 respondents. The research instrument used was the DASS questionnaire, analyzed with the Wilcoxon Match Pairs Test using an error level of 0.05, then Ztable (1.645) <Zhitung (3.295). The results showed that there was an effect of health education on third trimester primigravida mothers about childbirth with video media on anxiety facing childbirth in the working area of Puskesmas Blabak Kediri. Educational media about childbirth can be varied so that it will increase the level of understanding and affect the anxiety of third trimester pregnant women who are going through the labor process.

\section{Keywords: Anxiety, Health Education, Video, Primigravida}

\section{Pendahuluan}

Berdasarkan Profil Kesehatan Jawa Timur target angka kematian ibu pada tahun 2014 sebesar 346 per 100.000 kelahiran hidup, tahun 2015 sebesar 305 per 100.000 kelahiran hidup, dan pada tahun 2016 menyatakan bahwa target sebesar 305 per 100.000 kelahiran hidup, angka ini mengalami penurunan pada tahun 2015, tahun 2016 target AKI masih sama dengan tahun 2015. Angka Kematian Ibu (AKI) Provinsi Jawa Timur tahun 2014 mencapai 93,53 per 100.000 kelahiran hidup, tahun 2015 mencapai 89,6 per 100.000 kelahiran hidup dan pada tahun 2016 AKI Provinsi Jawa Timur mencapai 91,00 per 100.000 kelahiran hidup. Angka ini mengalami peningkatan dibandingkan tahun 2015 meskipun tidak terlalu signifikan. Penyebab tertinggi kematian ibu dari tahun 2012 hingga 2016 adalah Pre Eklamsi/Eklamsi. Pada tahun 2016 kejadian Pre Eklamsi/Eklamsi yaitu sebesar 30,90\% atau sebanyak 165 orang. ${ }^{6}$

Kehamilan pertama bagi seorang ibu (primigravida) merupakan salah satu periode krisis dalam kehidupannya. ${ }^{16}$ Primigravida sering memiliki pikiran yang mengganggu, sebagai pengembangan reaksi kecemasan terhadap cerita yang diperolehnya. Hal itu menyebabkan muncul ketakutan-ketakutan pada ibu primigravida yang belum memiliki pengalaman bersalin. ${ }^{21}$

Setiap ibu yang akan memasuki masa persalinan maka akan muncul perasaan takut, khawatir, ataupun cemas terutama pada ibu primigravida/primipara. Perasaan cemas dapat meningkatkan nyeri, otot-otot menjadi tegang dan ibu menjadi cepat lelah yang pada akhirnya akan menghambat proses persalinan. ${ }^{20}$

Masalah yang biasanya terjadi selama kehamilan pada ibu hamil baik primigravida maupun multigravida yaitu perasaan cemas. Kecemasan adalah kebingungan, kekhawatiran pada sesuatu yang akan terjadi dengan penyebab yang tidak jelas dan dihubungkan dengan perasaan tidak menentu dan tidak berdaya. ${ }^{17}$ Ketika ibu merasa sangat cemas menghadapi persalinan, secara otomatis otak mengatur dan mempersiapkan tubuh untuk merasa sakit, akibatnya saat persalinan nanti persepsinya nyeri semakin meningkat. ${ }^{4}$ Kondisi psikologis yang dialami oleh ibu akan sangat berpengaruh terhadap perkembangan bayi (Sulistyawati, 2009). Faktor-faktor maternal seperti kecemasan, kurang persiapan dan rasa takut dapat berinteraksi dengan faktorfaktor lain yang menyebabkan partus lama. ${ }^{11}$

Salah satu faktor yang menyebabkan kecemasan adalah pengetahuan yang rendah pada ibu primigravida tentang persalinan. ${ }^{9}$ Saran bagi wanita hamil, khususnya pada kehamilan pertama adalah mencari serta menggali informasi yang berkaitan 
dengan kesehatan fisik serta mental selama kehamilan, persalinan, pascasalin, dan perawatan bayi. Informasi tersebut sebaiknya diberikan oleh tenaga yang profesional dan berpengalaman agar informasi diperoleh dengan tepat. ${ }^{3}$

Upaya yang dapat dilakukan adalah salah satunya dengan memberikan informasi dan pendidikan kesehatan tentang persiapan persalinan dan proses melahirkan. ${ }^{13}$ Menurut Pendidikan kesehatan adalah upaya yang direncanakan untuk mempengaruhi orang lain, baik individu, kelompok, atau masyarakat sehingga mereka melakukan apa yang diharapkan oleh pelaku pendidikan. Selain itu, kegiatan untuk membentuk atau meningkatkan pengetahuan, sikap, dan praktik dalam memelihara dan meningkatkan kesehatan masyarakat secara mandiri. ${ }^{8,10}$

Penelitian Ernawati, N dan Hernowo, D (2015) yaitu pengaruh pemberian pendidikan kesehatan tentang proses persalinan terhadap tingkat kecemasan ibu primigravida trimester III, hasil penelitian menunjukkan bahwa sebelum diberikan pendidikan kesehatan terdapat $7 \mathrm{ibu}$ hamil yang mengalami kecemasan berat dan 5 orang mengalami kecemasan ringan hal ini disebabkan karena ibu hamil belum pernah mendapatkan informasi. Setelah diberikan pendidikan kesehatan tentang proses persalinan terdapat 9 orang mengalami kecemasan ringan dan 3 orang mengalami kecemasan sedang, dapat disimpulkan bahwa ada pengaruh pemberian pendidikan kesehatan tentang proses persalinan terhadap tingkat kecemasan ibu hamil primigravida trimester III. ${ }^{5}$

Media akan membantu dalam melakukan pendidikan kesehatan masyarakat, karena pesan-pesan kesehatan dapat disampaikan secara lebih jelas, sehingga sasaran (ibu hamil) akan menerima pesan tersebut dengan jelas dan tepat. ${ }^{14}$ Salah satu media efektif yang digunakan untuk menyampaikan pendidikan kesehatan adalah menggunakan media audio visual. Dengan metode audiovisual ini memberikan pengalaman secara nyata kepada responden karena dapat melihat, mendengar secara langsung tentang hal-hal yang sedang dipelajari. ${ }^{15}$

Berdasarkan hasil studi pendahuluan yang dilakukan di Wilayah Kerja Puskesmas Blabak dari $5 \mathrm{ibu}$ hamil primigravida trimester III yang diwawancara mengenai kecemasan menghadapi persalinan didapatkan 4 orang $(80 \%)$ memiliki rasa cemas jika menghadapi persalinan, karena belum mengeetahui gambaran persalinan dan apa yang akan terjadi pada proses persalinan tersebut. Metode penyuluhan yang dilaksanakan pada kelas ibu hamil baik pada K1 maupun K4 yaitu dengan wawancara, menggunakan leaflet dan buku KIA sebagai alat bantu untuk menjelaskan informasi kepada ibu hamil. Berdasarkan uraian di atas, penulis tertarik melakukan penelitian tentang Pengaruh Video tentang Persalinan dengan Media Video terhadap Kecemasan Menghadapi Persalinan pada Ibu Primigravida Trimester III di Wilayah Kerja Puskesmas Blabak.

\section{Metode Penelitian}

Desain yang digunakan dalam penelitian ini adalah pra eksperimen dengan rancangan One Group Pretest Posttest.Populasi dalam penelitian ini adalah semua ibu hamil primigravida trimester III yang ada di wilayah kerja Puskesmas Blabak Kabupaten Kediri yang berjumlah 15 responden. Sampel yang digunakan untuk penelitian adalah 
sebagian ibu hamil Primigravida Trimester III yang ada di wilayah Kerja Puskesmas Blabak Kabupaten Kediri yang memenuhi kriteria inklusi, sejumlah 14 orang. Teknik sampling yang digunakan dalam penelitian ini adalah simple random sampling. Alat pengumpulan data dalam penelitian ini adalah kuesioner untuk mengumpulkan data umum ibu hamil, kuesioner yang dimodifikasi dari skala DASS (Depression Anxiety Stress Scales) untuk mengukur kecemasan responden. Analisa data yang digunakan pada penelitian ini dengan menggunakan Wilcoxon Match Pairs Test.

\section{Hasil dan Pembahasan}

1. Kecemasan Ibu hamil primigravida trimester III dalam menghadapi persalinan sebelum diberikan pendidikan kesehatan.

Tabel 1. Kecemasan ibu primigravida trimester III sebelum diberikan intervensi

\begin{tabular}{clcc}
\hline No & Tingkat Kecemasan & Jumlah (n) & Persentase (\%) \\
\hline 1 & Tidak ada kecemasan & 2 & 14 \\
2 & Kecemasan ringan & 2 & 14 \\
3 & Kecemasan sedang & 4 & 29 \\
4 & Kecemasan berat & 2 & 14 \\
5 & Kecemasan berat sekali & 4 & 29 \\
\hline & Total & $\mathbf{1 4}$ & $\mathbf{1 0 0}$ \\
\hline
\end{tabular}

Tabel 1 menunjukkan bahwa sebagian besar responden sebelum diberikan pendidikan kesehatan tentang persalinan mengalami kecemasan sedang dan kecemasan berat sekali yaitu masing-masing sebesar 4 responden $(29 \%)$.

2. Kecemasan Ibu hamil primigravida trimester III dalam menghadapi persalinan setelah diberikan pendidikan kesehatan.

Tabel 2. Kecemasan ibu primigravida trimester III setelah diberikan intervensi

\begin{tabular}{clcc}
\hline No & \multicolumn{1}{c}{ Tingkat Kecemasan } & Jumlah (n) & Persentase (\%) \\
\hline 1 & Tidak ada kecemasan & 4 & 29 \\
2 & Kecemasan ringan & 5 & 36 \\
3 & Kecemasan sedang & 3 & 21 \\
4 & Kecemasan berat & 2 & 14 \\
5 & Kecemasan berat sekali & 0 & 0 \\
\hline & Total & $\mathbf{1 4}$ & $\mathbf{1 0 0}$
\end{tabular}

Berdasarkan tabel 2, sebagian besar responden (36\%), setelah diberikan pendidikan kesehatan tentang persalinan memiliki kecemasan dengan kategori kecemasan ringan, yaitu 5 responden.

3. Perubahan kecemasan ibu primigravida trimester III dalam menghadapi persalinan sebelum dan sesudah diberikan pendidikan kesehatan tentang persalinan dengan media video. 
Tabel 3 Perubahan Kecemasan Ibu Primigravida Trimester III

\begin{tabular}{lcccccccc}
\hline \multirow{2}{*}{$\begin{array}{l}\text { Kecemasan } \\
\text { Sebelum } \\
\text { diberikan } \\
\text { intervensi }\end{array}$} & \multicolumn{9}{c}{ Kecemasan Setelah diberikan intervensi } & Total & $\begin{array}{c}\text { Z } \\
\text { hitung }\end{array}$ \\
\cline { 2 - 9 } & $\begin{array}{l}\text { Tidak } \\
\text { ada }\end{array}$ & Ringan & Sedang & Berat & $\begin{array}{c}\text { Berat } \\
\text { sekali }\end{array}$ & & & \\
\cline { 2 - 10 } & $\mathrm{n}$ & $\mathrm{n}$ & $\mathrm{n}$ & $\mathrm{n}$ & $\mathrm{n}$ & $\mathrm{n}$ & $\%$ & \\
\hline Tidak ada & 2 & 0 & 0 & 0 & 0 & 2 & 14 & \\
Ringan & 2 & 0 & 0 & 0 & 0 & 2 & 14 & \\
Sedang & 0 & 4 & 0 & 0 & 0 & 4 & 28 & $-3,295$ \\
Berat & 0 & 1 & 1 & 0 & 0 & 2 & 14 & \\
Berat sekali & 0 & 0 & 2 & 2 & 0 & 4 & 28 & \\
\hline Total & 4 & 5 & 3 & 2 & 0 & 14 & 100 & \\
\hline
\end{tabular}

Berdasarkan tabel 4, diketahui bahwa terjadi perubahan kecemasan dalam menghadapi persalinan pada ibu primigravida trimester III. Sebelum diberikan pendidikan kesehatan kecemasan dalam menghadapi persalinan sebagian besar dalam kategori kecemasan sedang dan kecemasan sangat berat. Dilihat dari jumlah responden dalam kategori tersebut yaitu masing-masing kategori berjumlah 4 responden. Setelah dilakukan pendidikan kesehatan tentang persalinan, kecemasan dalam menghadapi persalinan dapat menurun dilihat dari jumlah responden dalam kategori kecemasan sedang dan kecemasan sangat berat berkurang yaitu kategori kecemasan sedang sejumlah 3 responden (21\%) dan kecemasan sangat besar sejumlah 0 responden $(0 \%)$.

Setelah dilakukan uji statistik Uji statistik menggunakan uji Wilcoxon Match Pairs Test, didapatkan nilai Z hitung yaitu sebesar -3,295, karena hasil perhitungan uji Wilcoxon ini merupakan harga mutlak maka harga (-) tidak diperhitungkan. Harga $Z$ tabel dengan taraf signifikan $(\alpha)$ 0,05 sebesar 1,645 maka didapatkan kesimpulan $\mathrm{Z}_{\text {hitung }}(3,295)>\mathrm{Z}_{\text {tabel }}(1,645)$ sehingga $\mathrm{H}_{0}$ ditolak dan $\mathrm{H}_{1}$ diterima yang berarti Ada pengaruh pendidikan kesehatan pada ibu primigravida trimester III tentang persalinan dengan media video terhadap kecemasan menghadapi persalinan di wilayah kerja Puskesmas Blabak.

Responden yang memiliki kecemasan dalam kategori kecemasan sangat berat berjumlah 4 orang (29\%) dengan jumlah jawaban terbanyak pada item skala kecemasan yaitu diantaranya cemas yang berlebihan dalam suatu situasi namun bisa lega jika hal/situasi itu berakhir, ketakutan, khawatir dengan situasi dimana mungkin menjadi panik. Hal ini sesuai dengan hasil penelitian menurut Maimunah, S (2009) tentang kecemasan ibu hamil menjelang persalinan pertama bahwa dari beberapa persentase tentang kecemasan yaitu kecemasan kondisi kehamilan dan keadaan diri, kecemasan calon bayi, kecemasan hal-hal seputar persalinan, dan kecemasan kondisi dan kesiapan diri dan keluarga, menunjukkan bahwa kecemasan tertinggi yang dialami oleh ibu primigravida trimester III ini adalah mengenai kecemasan hal-hal seputar persalinan $(57,8 \%)$ dan kecemasan terendah adalah kecemasan kondisi dan kesiapan diri dan keluarga (4,4\%). Masalah pada penelitian ini adalah muncul cerita-cerita negatif seputar persalinan merupakan hal yang sangat dicemaskan oleh ibu hamil di trimester tiga ini. Hal ini karena usia kehamilannya sudah mendekati proses persalinan. 
Pada penelitian ini sebagian besar responden belum mendapatkan informasi mengenai proses persalinan yaitu $11(79 \%)$ dari 14 responden sehingga kecemasan yang dialami responden dapat terjadi karena salah satu faktor yaitu kurangnya pengetahuan atau informasi mengenai persalinan yang mempengaruhi kecemasan ibu primigravida trimester III dalam menghadapi persalinan. Pernyataan tersebut sesuai dengan yang dikutip oleh Mansur dan Budiarti, (2014) menyatakan bahwa Pengetahuan yang rendah mengakibatkan seseorang mudah mengalami kecemasan. Ketidaktahuan tentang suatu hal dianggap sebagai tekanan yang dapat mengakibatkan krisis sehingga dapat menimbulkan kecemasan. Kecemasan dapat terjadi pada ibu dengan pengetahuan yang rendah mengenai proses persalinan. Hal ini disebabkan karena kurangnya informasi yang diperoleh. ${ }^{9}$

Setelah diberikan intervensi menunjukkan bahwa terjadi penurunan kecemasan pada ibu primigravida trimester III dalam menghadapi persalinan. Skor kecemasan yang didapatkan responden dari hasil post test tertinggi yaitu 16 dan terendah yaitu 4. Sebagian besar responden memiliki kategori tidak ada kecemasan dan kecemasan ringan dikarenakan responden mendapatkan informasi tentang persalinan dengan media video yang diberikan oleh peneliti. Hasil penelitian Ernawati, N dan Hernowo, D (2015) yaitu pengaruh pemberian pendidikan kesehatan tentang proses persalinan terhadap tingkat kecemasan ibu primigravida trimester III, menunjukkan bahwa sebelum diberikan pendidikan kesehatan terdapat $7 \mathrm{ibu}$ hamil $(58,3 \%)$ yang mengalami kecemasan berat dan 5 orang $(41,7 \%)$ mengalami kecemasan ringan hal ini disebabkan karena ibu hamil belum pernah mendapatkan informasi. Setelah diberikan pendidikan kesehatan tentang proses persalinan terdapat 9 orang (75\%) mengalami kecemasan ringan dan 3 orang (25\%) mengalami kecemasan sedang, dapat disimpulkan bahwa ada pengaruh pemberian pendidikan kesehatan tentang proses persalinan terhadap tingkat kecemasan ibu hamil primigravida trimester III. ${ }^{5}$

Diketahui dalam penelitian ini sebagian besar responden mengalami perubahan kecemasan dari kategori kecemasan yang tinggi menurun menjadi kategori kecemasan yang lebih rendah dan 2 responden (14\%) yang tetap dalam kategori tidak ada kecemasan namun skor nilai yang didapatkan menurun. Dikarenakan pemberian pendidikan kesehatan dengan menggunakan media video dapat meningkatkan pengetahuan dan sangat memungkinkan dapat menurunkan kecemasan pada ibu primigravida dalam menghadapi persalinan.

Sesuai dengan hasil penelitian Arafah dan Aizar meneliti tentang kecemasan ibu primigravida dalam menghadapi persalinan di klinik $\mathrm{Hj}$. Hadijah Medan setelah menonton video proses persalinan normal, menunjukkan bahwa menonton video persalinan dapat menurunkan kecemasan pada ibu hamil dalam menghadapi persalinan. Dapat disimpulkan bahwa tingkat kecemasan sebelum menonton video proses persalinan memperlihatkan bahwa mayoritas responden mengalami kecemasan berat sebanyak 8 orang, kecemasan sedang 6 orang dan kecemasan ringan 1 orang. Tingkat kecemasan sesudah menonton video proses persalinan menunjukkan perubahan, dimana rata-rata tingkat kecemasan responden 
dalam menghadapi proses persalinan adalah kecemasan sedang sebanyak 13 orang, kecemasan berat 1 orang dan kecemasan ringan 1 orang. ${ }^{2}$

Penggunaan salah satu media yang efektif digunakan untuk menyampaikan pendidikan kesehatan yaitu menggunakan media audio visual seperti media video dikarenakan dengan media audio visual dapat melibatkan banyak panca indra (penglihatan, pendengaran, perasaan) sehingga penyerapan informasi lebih baik. Hal ini dikarenakan banyak manfaat yang didapatkan dengan menggunakan media audio visual. Manfaat media audio visual yaitu : Menarik perhatian, penonton dapat memperoleh informasi dari para ahli atau spesialis, dapat mempermudah demonstrasi yang dianggap sulit, kontrol sepenuhnya dipegang oleh guru atau pemberi pendidikan kesehatan, dapat diputar pada ruangan yang bercahaya, rekaman dapat diputar atau ditayangkan berulang kali, hemat waktu, dan volume dapat diatur sesuai keinginan. ${ }^{14}$

Hasil penelitian Susanti, E yang meneliti perbandingan penggunaan media video dan metode ceramah dampak perilaku seksual pranikah terhadap pengetahuan dan sikap remaja di Kabupaten Rejang Lebong, menunjukkan remaja yang diberikan media video memiliki tingkat pengetahuan dan sikap yang lebih baik dari remaja yang diberikan metode ceramah $(\mathrm{p}<0,05)$. Penggunaan media video memberikan peluang peningkatan pengetahuan sebesar 1,52 kali dan peluang peningkatan sikap sebesar 1,57 kali dibandingkan menggunakan metode ceramah. Simpulan dalam penelitian ini adalah penggunaan media video mempunyai pengaruh yang lebih baik dalam meningkatkan pengetahuan dan sikap remaja dibandingkan dengan menggunakan metode ceramah. ${ }^{18}$

\section{Pengaruh Pendidikan Kesehatan pada ibu primigravida trimester III tentang persalinan dengan media video terhadap kecemasan dalam menghadapi persalinan}

Pemberian informasi atau pendidikan kesehatan dengan media video tentang persiapan menjelang persalinan baik fisik maupun psikis, dan informasi mengenai proses persalinan yang akan dihadapi nanti dapat membuat ibu hamil lebih siap dan lebih percaya diri dalam menghadapi proses persalinan sehingga kecemasan dalam menghadapi persalinan dapat menurun seperti yang terdapat pada hasil penelitian yang telah dilakukan oleh peneliti yaitu terjadi penurunan kecemasan dalam menghadapi persalinan pada ibu primigravida trimester III di wilayah kerja Puskesmas Blabak.

Hal ini sesuai dengan kutipan dalam buku Rukiyah Informasi dan pendidikan kesehatan: mengurangi pengaruh yang negatif misalnya kecemasan dan ketakutan sering ditimbulkan oleh cerita-cerita yang menakutkan mengenai kehamilan dan persalinan, pengalaman persalinan yang lampau atau karena kurangnya pengetahuan mengenai proses kehamilan dan persalinan. Keadaan tersebut perlu diimbangi dengan pendidikan mengenai anatomi dan fisiologi kehamilan dan persalinan kepada ibu hamil. ${ }^{11}$

Menurut Aprilia dalam penelitian Arafah dan Aizar menyatakan bahwa video melahirkan dimaksudkan untuk menunjukkan kepada calon ibu bagaimana proses kelahiran itu terjadi. Video melahirkan dapat membantu para calon ibu 
memvisualisasikan bagaimana bayinya bergerak melalui jalan lahir selama persalinan. Dengan demikian akan membantu para calon ibu memiliki pandangan positif dari tahap persalinan dan mempersiapkan diri untuk menghadapi persalinan. Setelah menonton video proses persalinan normal, menunjukkan bahwa menonton video persalinan dapat menurunkan kecemasan pada ibu hamil dalam menghadapi persalinan. Dapat disimpulkan bahwa tingkat kecemasan pre menonton video proses persalinan memperlihatkan bahwa mayoritas responden mengalami kecemasan berat sebanyak 8 orang, kecemasan sedang 6 orang dan kecemasan ringan 1 orang. Tingkat kecemasan post menonton video proses persalinan menunjukkan perubahan, dimana rata-rata tingkat kecemasan responden dalam menghadapi proses persalinan adalah kecemasan sedang sebanyak 13 orang, kecemasan berat 1 orang dan kecemasan ringan 1 orang. ${ }^{2}$

Upaya dalam menurunkan kecemasan pada ibu primigravida trimester III dalam menghadapi persalinan tidak hanya didapatkan dari mengikuti pendidikan kesehatan saja, melainkan dengan menerapkan informasi yang telah didapatkan dalam kehidupan nyata dengan didampingi oleh keluarga khususnya suami, maupun tenaga kesehatan. Semakin sering ibu hamil melakukan atau menerapkan informasi untuk mengurangi kecemasan dalam menghadapi persalinan, maka kecemasan ibu hamil tersebut akan mengalami penurunan.

\section{Kesimpulan}

Berdasarkan hasil penelitian yang telah dilakukan maka dapat disimpulkan bahwa sebelum diberikan pendidikan kesehatan tentang persalinan dengan media video sebagian besar kecemasan pada ibu primigravida trimester III memiliki tingkat kecemasan sangat berat dan kecemasan sedang, namun setelah diberikan pendidikan kesehatan tentang persalinan dengan media video sebagian besar kecemasan pada ibu primigravida trimester III memiliki tingkat kecemasan ringan. Sehingga ada pengaruh pemberian pendidikan kesehatan pada ibu primigravida trimester III tentang persalinan dengan media video terhadap kecemasan menghadapi persalinan.

\section{Daftar Pustaka}

1. Aqib, Z \& Murtadlo, A. 2016. Kumpulan Metode Pembelajaran Kreatif dan Inovatif. Bandung: Satu Nusa

2. Arafah, C.T dan Aizar, E. 2012. Kecemasan Ibu Primigravida dalm Menghadapi Persalinan di Klinik $\mathrm{Hj}$. Hadijah Medan Setelah Menonton Video Proses Persalinan Normal. Jurnal USU. http://jurnal.usu.ac.id/index.php/jkk/article/download/325/198.

3. Dahro, A. 2012. Psikologi Kebidanan: Analisis Perilaku Wanita Untuk Kesehatan. Jakarta: Salemba Medika

4. Danuatmaja, B. 2008. Persalinan Normal tanpa Rasa Sakit. Jakarta: Puspa Swara

5. Ernawati, N dan Hernowo, D. 2015. Pengaruh Pemberian Pendidikan Kesehatan Tentang Proses Persalinan Terhadap Tingkat Kecemasan Ibu Primigravida Trimester III. Jurnal Kesehatan Hesti Wira Sakti. Volume 3, Nomor 3 https://jurnal.poltekkessoepraoen.ac.id/index.php/HWS/rt/printerFriendly/110/0 
6. Kemenkes RI. 2016. Profil Kesehatan Provinsi Jawa Timur Tahun 2016. Surabaya: Dinas Kesehatan Provinsi Jawa Timur

7. Maimunah, S. 2009. Kecemasan Ibu Hamil Menjelang Persalinan Pertama. Universitas Muhammadiyah Malang. Jurnal HUMANITY, Vol.V, No.1, Hal.6167. Skripsi http://ejournal.umm.ac.id/index.php/humanity/article/view/830.

8. Mandriwati, G.A. 2011. Asuhan Kebidanan Antenatal : Penuntun Belajar. Jakarta: EGC

9. Mansur, H \& Budiarti, T. 2014. Psikologi Ibu Dan Anak Untuk Kebidanan. Jakarta: Salemba Medika

10. Notoatmodjo, S. 2012. Promosi Kesehatan dan Perilaku Kesehatan. Jakarta: Rineka Cipta

11. Padila. 2014. Buku Ajar Keperawatan Maternitas. Yogyakarta: Nuha Medika

12. Rukiyah, A.Y, dkk. 2009. Asuhan Kebidanan I (Kehamilan). Jakarta: TIM

13. Rukiyah, A.Y, dkk. 2009. Asuhan Kebidanan II (Persalinan). Jakarta: TIM

14. Suiraoka, I.P, dkk. 2012. Media Pendidikan Kesehatan. Yogyakarta: Graha Ilmu

15. Sulistyawati, A. 2009. Asuhan Kebidanan pada Masa Kehamilan. Jakarta: Salemba Medika

16. Sulistyorini, RR. I. R. 2007. Hubungan Antara Dukungan Keluarga Dengan Kecemasan Ibu Hamil Menghadapi Kelahiran Anak Pertama Pada Masa Triwulan Ketiga. Skripsi

17. Suliswati, dkk. 2005. Konsep Dasar Keperawatan Kesehatan Jiwa; ed. Monica Ester. Jakarta: EGC

18. Susanti, E, dkk. 2015. Perbandingan penggunaan media video dan metode ceramah dampak perilaku seksual pranikah terhadap pengetahuan dan sikap remaja di kabupaten rejang lebong. Bengkulu: Universitas Padjajaran. IJEMC, Vol.2, No.3 http://www.ijemc.unpad.ac.id/ijemc/article/download/60/49.

19. Supranto. 2007. Teknik Sampling untuk Survey dan Eksperimen. Jakarta: PT Asdi Mahasatya

20. Walyani \& Purwoastuti. 2016. Asuhan Kebidanan Persalinan dan Bayi Baru Lahir. Yogyakarta: PUSTAKA BARU PRES

21. Wulandari, P. Y. 2006. Efektivitas Senam Hamil Sebagai Pelayanan Prenatal Dalam Menurunkan Kecemasan Menghadapi Persalinan Pertama. Surabaya: Universitas Airlangga. 